\title{
22 THE USE OF WETLAND FOR STORMWATER POLLUTION CONTROL
}

\author{
Mindaugas Rimeika \\ Vilnius Gediminas Technical University, Lithuania
}

\begin{abstract}
Developing and implementing a stornwater management strategy requires several key components. Research must be undertaken to develop local rainfall distribution statistics, determine stormwater pollutant loading characteristics, determine the effectiveness of various stormwater treatment practices and identify design criteria for each type of the best management practice. The practice of urban stormwater management has until recently focused only on drainage and flood control. But now days more and more concern are taken to reduce pollution's wash out loads to water recipients by implementing source control management, on-site treatment and building stormwater pollution control facilities. In the article overview and basic principals of stormwater quality management are presented. General stormwater treatment and pollutant removal mechanisms are explained. Summary results of study of the pollution removal in constructed wetlands for stormwater treatment are described.
\end{abstract}

\section{KEYWORDS}

Stormwater, rain depth, runoff, stormwater pollution, stormwater treatment, wetland, wet pond, water plants.

\section{INTRODUCTION}

Growing cities and industries, urbanization and technical development cause bigger runoff volume, increased pollution and negative effects on the environment. Numbers of the research reports showed the deterioration tendency of water recipients even then waste water effluent has properly treatment $(1,6,10,11)$. Stormwater (rain, snow and melt water) flush organic and inorganic matters, soluble and suspended solids, nutrient, metals, bacteria and litter from urbanized area to the water recipient. In additional rainfall is natural way for removal of dust, aerosol, gas and other particle from air. Rain and snow moving through the lower layer of the atmosphere absorb the big part of air pollutants and reach the earth surface already contaminated. Classes of pollutants typically monitored in stormwater quality studies include suspended solids (SS), heavy metals, nutrients, organics, oxygen demanding substances and bacteria. Almost all snow and ice control measures contribute sand and salts, and only matter of time when they will reach water body. Therefore, urban stormwater runoff is recognized as a major source of pollution, that adversely affects the quality of the receiving water $(3,5,9)$. Urban runoff that has the influence on receiving waters could be classified as changes to: stream hydrology, water quality, water habitant, ecology, sanitary and social aspects. In urban area the amount of impervious surface area (streets, roofs, parking lots, driveways and sidewalks) is increased comparing with natural land. The increased runoff volumes are results 
in the decreased infiltration and storage depression. And therefore streams receive more runoff then from the same size natural watershed. Runoff washes everything on its way, transports huge amount of pollution loads to recipients and causes the problems to water quality and life environment of water habitant, and limits stream use for recreation $(5,10)$.

There are a lot of different ways to reduce negative impacts of stormwater to environmental. Some of them relaying to good housekeeping, properly city design and public education, but almost always necessary implement some kind of stormwater treatment facilities.

\section{STORMWATER QUALITY MANAGEMENT}

The basics objective of stormwater management is improvement of water quality in drainage watershed, reduction runoff volumes and enhanced beneficial use of the receiving water bodies and constructed treatment facilities. The current practice is to presume that a costeffective, practicable set of the best management practices (restrictions, techniques, or treatment facilities that are required under given conditions) will provide some progress protecting water quality. Stormwater management strategy could be divided in two main groups (without doubt, both of them have a strong relationship):

$>$ stormwater pollution reduction;

runoff volume reduction.

Volume and pattern of rainfall do not depend on our wishes, and we can not regulate or make influence on them. But rainfall transformation process to runoff we more or less could regulate in urban areas. It could be done by properly design of watershed, minimization of directly connected impervious area, introduction of infiltration practice and other BMPs methods $(1,11)$.

Stormwater pollution depends on numbers of factors, the most important are the following: pollution of atmosphere, rainfall characteristics, pedestrian and traffic intensity, maintenance of road, pattern and function of watershed, dry period and others. The following three basic objectives could be involved to improve urban stormwater quality:

$>$ source control;

$>$ on-site treatment;

$>$ end-of-pipe techniques.

Source control strategy should ensure that pollution would never reach earth surface. Source control efficiency has a strong relationships with public education on proper use and disposal of household chemicals, litter, paints, solvents, motor oil, pesticides, herbicides, fertilizers, antifreezes, etc. Other focus turn to land development and redevelopment process, such as detection and elimination of illicit discharges of wastewater lines to separate storm sewers, street sweeping, leaf pickup, efficient street de-icing programs, control accidental spills, enforce clear violation of ordinances designed to prevent the deposition of pollutants on the urban landscape $(2,3,4,5)$.

An on-site stormwater treatment facility in general means reduction of runoff volume. Such facilities could serve small sites of about two to four hectares of tributary paved surface. Onsite facilities also include use of minimized directly connected impervious area. However this practice could be implemented in newly developing and redeveloping areas. It relies on nontraditional layout of urban streets, parking lots and buildings, and use grass buffers, roadside grass swales instead of curd and gutter, porous pavement, percolation trench and infiltration basins.

End-of-pipe techniques are generally recognized as some kind of stormwater treatment facilities, such as dry ponds, dry extended ponds, wet ponds, shallow marsh systems, 
wetlands, sand filter and others. Each of them has numbers of advantages and disadvantages, which are perfectly described in technical literature $(1,6,9,11)$.

\section{STORMWATER TREATMENT CONCEPTION}

From an analysis of literature, our experience in stormwater management and statistical analysis of rainfall data the following conclusions could be made:

1. Precipitation is the driving force that mobilizes and transports pollutants from urban territory to receiving water. Relevant information on the precipitation characteristics of an area is essential to address issues as an estimation of non-point pollution loads, the water quality impacts, and an assessment of control strategies. All rainfall characteristics have big variance over the time period in certain area. Most important rainfall parameters for design stormwater treatment facilities are daily rainfall depth, pattern and duration, average and probability distribution of rainfall event depths and dry periods and rainfall intensity.

2. Rainfall intensity and runoff pollution have the strong relationship. Intensive rainfalls cause a bigger runoff, which flash out a bigger amount of pollutants. Of course flush out pattern depend not only on rainfall intensity, but also on season, land use, watershed slope, traffic intensity, dry period and other factors. The concentration of stormwater pollution has a great variation during one rain, and the same could be said about event mean concentration and event pollution load.

3. Suspended solids have a good correlation with other stormwater quality constituents and are widely used as an indicator of stormwater quality. The biggest part of stormwater contaminants is associated with small particles of suspended solids. Therefore removal of suspended solids form stormwater is the main issue. If we remove the suspended solids from the stormwater we will remove the big part of other contaminants, such as heavy metals, organics and oil. The easiest way for SS removal is settling. Effluent quality from settling tank depends on retention time, tank depth and flow velocity.

4. Adsorption, chemical reaction and biological treatment could remove dissolved solids, metals and nutrients. The most powerful treatment is self-nature cleaning. We could make only appropriate condition for improving self-cleaning activity.

Taking all above mention into consideration, it is clear that physical, chemical and biological treatment mechanisms should be applied for stormwater treatment. Understanding these mechanisms is the basis for determining effective treatment systems. That understanding should be applied to entire process, from conception of the project, through preliminary planning and all phases of implementation, and finally, to the long-term operation of the systems. Summary the various pollutant removal mechanisms are presented in Table1.

Nitrogen removal as usual is not possible (except plant uptake), because processes requires alternating aerobic and anaerobic conditions, which difficult to achieve in stormwater treatment facilities. 
Table 1. Mechanisms for pollutant removal in constructed wetland

\begin{tabular}{|c|c|c|}
\hline Mechanism & Pollutants affected & Promoted by \\
\hline $\begin{array}{l}\text { Physical } \\
\text { Sedimentation }\end{array}$ & $\begin{array}{l}\text { Solids, BOD, pathogens; particulate } \\
\text { COD, P, N, metals, organics }\end{array}$ & Low turbulence \\
\hline Filtration & $\begin{array}{l}\text { Solids, BOD, pathogens; particulate } \\
\text { COD, P, N, metals, organics }\end{array}$ & $\begin{array}{l}\text { Fine textured soil and dense } \\
\text { water plants }\end{array}$ \\
\hline $\begin{array}{l}\text { Chemical } \\
\text { Adsorption }\end{array}$ & Dissolved P, metals, organics & High soil organics \\
\hline Oxidation & COD, petroleum hydrocarbons, organics & Aerobic conditions \\
\hline Photolysis & $\mathrm{COD}$, petroleum hydrocarbons, organics & High light \\
\hline Volatilization & $\begin{array}{l}\text { Volatile petroleum hydrocarbons, } \\
\text { organics }\end{array}$ & $\begin{array}{l}\text { High temperature and air } \\
\text { movement }\end{array}$ \\
\hline $\begin{array}{l}\text { Blological } \\
\text { Microbial } \\
\text { decomposition }\end{array}$ & $\mathrm{BOD}, \mathrm{COD}$, organics & $\begin{array}{l}\text { High plant surface area and } \\
\text { soil organics }\end{array}$ \\
\hline Plant uptake & $\mathrm{P}, \mathrm{N}$, metals, organics & $\begin{array}{l}\text { High plant activity and } \\
\text { metabolism and surface area }\end{array}$ \\
\hline
\end{tabular}

In order to achieve comprehensive stormwater treatment efficiency all above mentioned pollutant removal mechanisms should be applied. From the overview of stormwater treatment facilities clear to see that constructed wetlands can potentially operate all of these mechanisms $(7,8)$. At the beginning of treatment a pond should be constructed. It accumulates big volumes of runoff, equalize pollution concentration, traps coarse sediments, reduces incoming velocities, and helps to distribute runoff evenly over the marsh. If it is necessary the pond inlet could be constructed to promote increase oxygen level in stormwater. After preliminary settling stormwater enters to shallow/high marsh system (wetland). The physical, chemical and biological stormwater treatment mechanisms take place here due to plant activity, slow flow, hydraulic conductivity, water depth and other factors. After the marsh systems stormwater enters to second wet pond for final polishing. Water from wet pond flows to effluent through the biological filter. It is constructed on the blanks of pond and planted with water plants. Sand and gravel bed filter keeps out remained solids and increases dissolved solids uptake rate by roots of the water plant. Plants are important element for overall treatment efficiency. They provide surface for bacteria growth and adsorption, filtration, nutrient assimilation and uptake of heavy metals. The roots of plants also provide effort for unclogging of filter bed.

\section{CASE STUDY}

The following case study provides an example of urban stormwater treatment wetland in Lithuania. Wetland, as pilot plant, was under operation from November of 1995 until December of 1996. So we have the results from one-year investigation. The main purpose for the pilot plant construction was to check out the new stormwater treatment technology, before building the big treatment facilities. Place located in the western part of Vilnius. The estimated gross area of catchment is more than 300 ha. Separated stormwater sewerage line 
(1,5 $\mathrm{m}$ diameter) discharged untreated stormwater into the Voke river. The drainage basin serves predominantly for industrial area.

\section{Sampling}

Water samples were taken by automatic sampler, developed and manufactured at the Department of Water Management. The samples were taken when stormwater level reach preset level. It was observed that below this level water flows were infiltrated water only. The taken samples were analyzed by $\mathrm{SS}, \mathrm{BOD}, \mathrm{COD}, \mathrm{Oil}, \mathrm{P}, \mathrm{N}, \mathrm{Cl}, \mathrm{SO}_{4}$ and others.

\section{Precipitation data}

At site the rain gauge was installed and obtained data was calibrated with data from official meteorological station that is located closed to the pilot plants. The mach between measurements of precipitation with local gauge and official gauge (placed at a distance about $4 \mathrm{~km}$ from local gauge) was very good, in spite of some local variations. Analyses of the pluviograph rainfall data between period of 1972-1996 were made. The average annual rainfall depth in Vilnius is $730 \mathrm{~mm}$, the biggest rainfall happens in July and August, $57,7 \mathrm{~mm}$ and $58,4 \mathrm{~mm}$ respectively. During the hot season (V-X months) on average of 6,3 rainfall events per month occur in Vilnius. From the statistical analysis it was derived that the minimum inter-event dry time between successive rainfall events is 16 hours, and the average rainfall depth is $9,4 \mathrm{~mm}$, and the average rainfall duration is 8,7 hours, and the average interevent dry time between two independed rainfall is 134 hours. The retention basins containing the runoff from average rainfall depth may treat $82 \%$ of hot season amount of precipitation. Rainfall events with bigger than average rainfall depth occur on average 9 times per year.

\section{Stormwater pollution}

Before the wetlands the following limits of stormwater pollution level were indicated: SS from 25 to $882 \mathrm{mg} / \mathrm{l}$ (median - $135 \mathrm{mg} / \mathrm{l})$, BOD - 5,5-22,0 mg/l (median - 9,9 mg/l); COD 24,5-184 mg/l (median - $80 \mathrm{mg} / \mathrm{l})$; dry residual 76-592 mg/l (median $-272 \mathrm{mg} / \mathrm{l})$; oil 0,4-3,1 $\mathrm{mg} / \mathrm{l}$ (median - 0,7 mg/l); total phosphorus $0,02-0,36 \mathrm{mg} / \mathrm{l}$ (median - 0,06 mg/l); total nitrogen 0,1-2,8 (median - 0,6 mg/l).

\section{Constructed wetland}

From the main storm sewer pipe the branch line to the pilot plant was made. Water flows that were diverted to the treatment regulated by throttling pipe. Average stormwater flow to the wetland was about $4 \mathrm{~m}^{3} / \mathrm{h}$. Changing the flow rate the treatment efficiency of pilot plant was tested. At inlet to treatment facilities the pond of $1,4 \mathrm{~m}$ depth was constructed. Retention time in the pond ranged from 6 to 18 hours. After settling stormwater flowed through shallow marsh system. At the end of facilities an additional pond was constructed. Size of both ponds was rather the same. On the one blank of the last pond biological sloped filter was arranged. At the bottom of pond a drainage pipe was inserted and over the drainage pipe reciprocal filter bed of 0,8-1,2 m high was constructed. The size of particles of that filter was from 0,8 up to $5,0 \mathrm{~mm}$, and porosity of filter media was about $27 \%$. The minimum water level of $0,6 \mathrm{~m}$ was kept to maintain the water plants, and maximum level of $1,55 \mathrm{~m}$ for short time was applied. Side slope of the bio-filter was constructed as 4:1. The bio-filter was planted with Scirpus, Typha, Iris and Phragmites respectively to depth. The water plants were planted at density of 4-10 plants per $\mathrm{m}^{2}$. Planted plants grown up very rapidly. Hydraulic loads of bio-filter varied from $0,3-0,8 \mathrm{~m}^{3} / \mathrm{m}^{2} / \mathrm{h}$, depending on settling time, flow velocity and concentrations of pollutants. In order to increase hydraulic load, it is possible to construct additional bottom 
filter, and arrange sloped bio-filters on other blanks of final pond. The efficiency of bottom filter was tested separately. After one-year operation no visible clogging in sloped bio-filter was obtained.

Principal lay out of pilot plant of constructed wetland is presented in Figure 1.

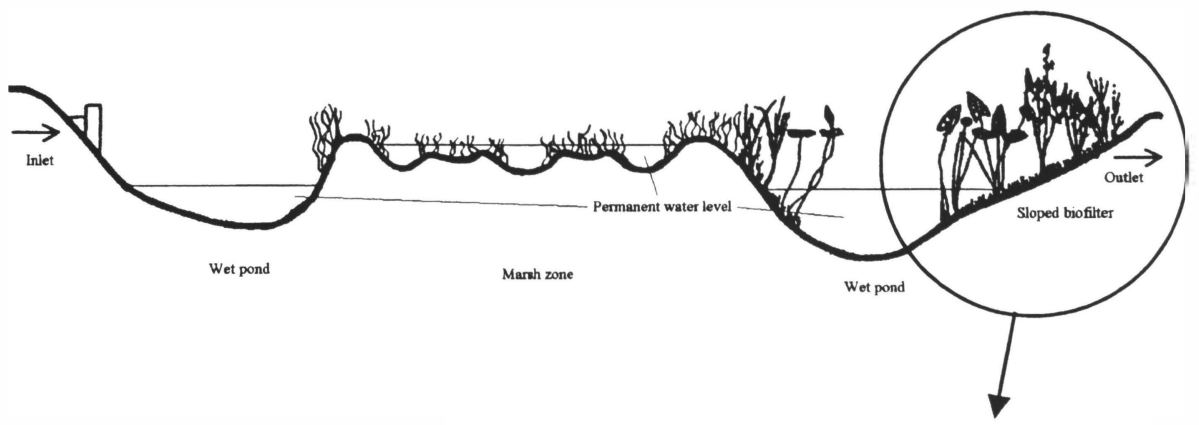

Legend.

1. Isolation;

6. Valves;

2.Sand; 7, 8, 9. Water

3. Course gravel;

4. Drainage pipes; plant: Scirpus, Typha, Iris 5. Flexible pipe; respectively; 10. Reinforced slope.

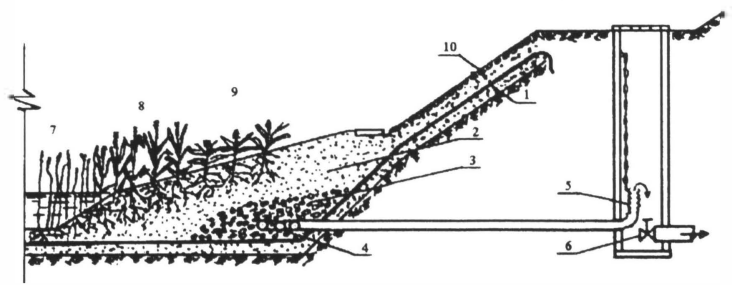

Figure 1. Constructed wetland design conception

\section{Constructed wetland treatment efficiency}

The overall treatment efficiency of constructed wetland is very good. Effluent concentrations are much lower than the requirements for stormwater discharge to water bodies. Average effluent concentration was the following: $4,8 \mathrm{mg} / \mathrm{l}$ of SS, $0,48 \mathrm{mg} / \mathrm{l}$ of oil, $0,8 \mathrm{mg} / \mathrm{l}$ of BOD, $28 \mathrm{mg} / \mathrm{l}$ of COD, $0,32 \mathrm{mg} / \mathrm{l}$ of total nitrogen, $0,03 \mathrm{mg} / \mathrm{l}$ of total phosphorus.

The treatment efficiency of stormwater facilities depends on numbers of parameters, among others they are settling time in ponds, properties of stormwater pollutants, year season, filtration rate, pollutants concentration, water plant selection and activity, treatment facilities layout.

\section{CONCLUSION}

Stormwater from urban area carrying significant source of pollution to receiving waters and cause thread to the environment. The implementation of different best management practices can reduce the negative effects. The choice of method (source control, on-site treatment or end-of-pipe techniques) depends on site-specific conditions.

In many countries there is an increasing trend in construction stormwater treatment facilities, such as ponds, wetlands, infiltration basins, filter strips. However clear guidelines on the design and operation of stormwater treatment facilities need to be established to ensure that each treatment plant achieves its potential for the pollution removal. 
Wetland is one of most promising stormwater pollution reduction facilities. In wetland physical, chemical and biological treatment mechanisms are applied. Nevertheless before stormwater enters to the wetland a proper pre-treatment should be performed.

Stormwater wetland treatment was tested in the pilot plant. The final polishing of stormwater in the sloped biological filter to conventional wetland layout was added. The obtained results showed good reatment efficiency and significant reduction of stormwater pollutants loads. Especially good treatment efficiency was observed at the low pollution concentration.

Designing wetland the general guidelines for stormwater treatment facilities, rainfall characteristics, watershed specifics, runoff pollution, soil pattern, site condition should be taken into consideration. Properly designed wetlands could be useful aim for downstream stormwater pollution control.

\section{REFERENCES}

1. Design and construction of urban stormwater management systems (1992). Manual of practices No. 77. USA.

2. Greb S. R., Bannerman R. T. (1997). Influence of particle size on wet pond effectiveness, Water Environmental Research, Vol. 69, No. 6, pp. 1134-1137.

3. Pettersson J. (1999). Stormwater ponds for pollution reduction. Doctoral thesis. Department of sanitary engineering. Chalmers University of Technology.

4. Pitt R., Field R., Lalor M., Brown M. (1995). Urban stormwater toxic pollutants: assessment, sources and treatability. Water Environmental Research, Vol. 67, No. 3, pp. 260-275.

5. Larm T. (2000). Watershed-based design of stormwater treatment facilities: model development ad application. Doctoral thesis. Royal Institute of Technology.

6. Schueler T.R (1987). Controlling Urban Runoff: A Practical Manual and Designing Urban BMPs. Metropolitan Washington Council of Goverments.

7. Shutes R. B. E., Revitt D. M., Mungur A. S., Scholes L. N. L (1997). The design of wetland systems for the treatment of urban runoff. Water science and technology, No. 35, Vol. 5, pp. 19-25.

8. Stecker E.W., Kersnar J.M., Driscoll E.D. (1992). The Use of Wetlands for Controlling Stormwater Pollution. The Terrene Institute.

9. Urbonas B., Stahre P. (1993). Stormwater. Best Management Practices and Detention for Water Quality, Drainage, and CSO Management. PTR Prentice Hall.

10. Urban Runoff Pollution (1986). Published in co-operation with NATO Scientific Affairs Division. Berlin.

11. Urban Runoff Quality Management (1998). WEF Manual of Practice No. 23, ASCE Manual and Report on Engineering Practice No. 87, USA. 